\title{
PENGEMBANGAN MODEL E-CAREER UNTUK MENINGKATKAN KEPUTUSAN KARIR SISWA SMA NEGERI 3 MAKASSAR
}

\author{
Fadilla Fasha \\ Bimbingan dan Konseling, Universitas Tompotika L uwuk \\ Email: fadillafasha@ymail.com \\ Abdullah Sinring \\ Bimbingan dan Konseling, FIP BK UNM \\ Email: abdullahsinring@yahoo.co.id \\ Farida Aryani \\ Bimbingan dan Konseling, Program Pascasarjana BK S2 UNM \\ Email: farayani77@yahoo.com
}

\begin{abstract}
This study examined the development of career information service model based on electronic media (e-career) to improve students' career decision at SMAN 3 Makassar. The purposes of this study were (1) to develop the acceptable electronic based media (e-career) of career information services model in improving students' career decision at SMAN 3 Makassar. The study was a research and development which referred to the research stages by Borg and Gall. The date of the study were collected by employing interviews, questionnaires, and scales of measurement, as well as the Focus Group Discussion (FGD) techniques. The results of the study revealed that (1) the development of the acceptable electronic-based media (e-career) of career information services model in improving students' career decisions obtained high rating scale from the experts and a very good response from the counseling teachers and students, where it was acceptable and feasible to be used in SMAN 3 Makassar; (2) The application of electronic-based media (e-career) of career information services model was effective in improving students career decision at SMAN 3 Makassar.
\end{abstract}

Keywords: E-career, career decision.

\begin{abstract}
Abstrak: Tujuan dari penelitian ini adalah (1) Untuk mengembangkan model layanan informasi karir berbasis media elektronik (e-career) yang acceptable (diterima) dalam meningkatkan keputusan karir siswa di SMA Negeri 3 Makassar (2) Untuk mengetahui efektivitas model layanan informasi karir berbasis media elektronik (e-career) dalam meningkatkan keputusan karir siswa SMA Negeri 3 Makassar. Penelitian ini adalah penelitian dan pengembangan (Research and Develpoment) yang berdasarkan tahapantahapan penelitian oleh Borg and Gall. Penelititan ini menggunakan teknik pengumpulan data melaluiwawancara, angket dan skala pengukuran, serta Focus Group Discussion (FGD).Hasil penelitian menunjukkan bahwa (1)Pengembangan model layanan informasi karir berbasis media elektronik (e-career) yangacceptable(diterima)untuk meningkatkan keputusan karir siswa mendapat skala penilaian tinggi dari para ahli dan respon yang sangat baik dari guru bimbingan konseling serta siswa yaitu dapat diterima dan layak untuk digunakan di SMA Negeri 3 Makassar (2) Penerapan model layanan informasi karir berbasis media elektronik (e-career) efektif dalam meningkatkan keputusan karir siswa SMA Negeri 3 Makassar.
\end{abstract}

Kata Kunci: E-career, Keputusan Karir.

PENDAHULUAN
Salah satu permasalahan yang seringkali dialami oleh siswa khususnya di tingkat SMA adalah ketidakmampuan atau sulitnya siswa 
membuat keputusan karir. Sebagian besar dari mereka belum mampu untuk memilih dan memutuskan arah pilihan karirnya ke depan. Hal ini disebabkan oleh kurangnya pengetahuan mereka tentang jurusan atau program studi yang akan mereka pilih ketika lulus SMA nanti, serta pekerjaan yang cocok dan sesuai dengan bakat dan kemampuannya. Seperti diketahui bahwa terkadang siswa memilih suatu jurusan atau program studi tanpa pertimbangan yang matang atau hanya mengikuti teman, tanpa melihat dan mempertimbangkan karakteristik, bakat serta kemampuan yang dimilikinya. Padahal memilih jurusan atau program studi yang cocok dan sesuai dengan bakat dan kemampuan serta kepribadian individu adalah hal yang sangat penting dan akan mempengaruhi perkembangan karir seseorang. Seperti halnya yang terjadi di SMA Negeri 3 Makassar, dimana banyak siswa yang masih bingung untuk menentukan arah pilihan karirnya atau memutuskan pilihan karir yang tepat untuk masa depannya nanti.

Berdasarkan analisis kebutuhan dengan menggunakan angket yang diberikan kepada 30 siswa kelas XII, didapatkan hasil yakni hanya sekitar 30\% siswa yang telah mampu mengambil keputusan karir, sementara $70 \%$ siswa lainnya belum dapat mengambil keputusan karir dan masih bingung untuk menentukan pilihan jurusan atau program studi yang tepat serta memilih bidang pekerjaan yang nantinya akan dia tekuni sesuai dengan bakat, minat serta kemampuannya. Hal ini semakin diperkuat oleh keterangan atau pernyataan dari guru BK di SMA Negeri 3 Makassar yang menyatakan bahwa banyak siswa yang sering datang menemui guru BK untuk mengonsultasikan atau menanyakan berbagai hal yang berkaitan dengan masa depan karirnya, baik itu yang menyangkut jurusan atau program studi apa yang sebaiknya mereka pilih di perguruan tinggi nanti, maupun jenis pekerjaan yang tepat dan sesuai dengan bakat dan kemampuan mereka. Sehingga dari hasil angket tersebut dapat kita simpulkan bahwa sebagian besar siswa belum mampu untuk menentukan atau memutuskan arah pilihan karirnya ke depan.

Masalah yang berkaitan dengan kematangan dan keputusan karir siswa memang menjadi permasalahan yang seringkali dihadapi oleh siswa pada umumnya. Diungkapkan oleh Leksana, Wibowo, \& Tadjri (2013) bahwa permasalahan karir pada remaja biasanya berkaitan dengan pemilihan jenis pendidikan, yang mengarah pada pemilihan jenis pekerjaan di masa depan, perencanaan karir, dan pengambilan keputusan tentang karir untuk masa depan, serta informasi tentang pekerjaan yang ada dengan persyaratan yang harus dimiliki.

Ketidakmampuan siswa dalam memilih, menentukan serta memutuskan arah pilihan karirnya seringkali memang disebabkan oleh kurangnya informasi yang diberikan oleh guru BK mengenai berbagai program studi atau jurusan yang ada di perguruan tinggi dan pekerjaan yang cocok, serta sesuai dengan minat dan kemampuannya.

Pemberian layanan informasi karir kepada siswa memiliki peranan penting untuk dapat membantu siswa dalam mengatasi permasalahan karirnya. Hal ini ditunjukkan oleh hasil penelitian yang dilakukan oleh Muslihatul dan Nursalim (2013) pada siswa SMA di Surabaya,yang mana ditemukan bahwa sekitar $45 \%$ siswa mengalami masalah dalam bidang karir dan pekerjaan, kemudian permasalahan ini ditindaklanjuti dengan memberikan tindakan berupa layanan infromasi karier dan didapatkan hasil yakni sekitar $80,15 \%$ siswa menyatakan bahwa mereka semakin mengetahui dan memahami tentang arah pilihan karirnya setelah diberikan layanan informasi karir. Begitu juga dengan penelitian yang dilakukan oleh Kurnianto (2010) pada siswa di SMA PGRI Slawi dimana pemberian layanan informasi bimbingan karir efektif terhadap ketepatan pemilihan karir siswa. Selain itu dalam penelitian tentang pemahaman cara membuat keputusan karir melalui layanan informasi karir yang dilakukan oleh Novitasari, Wibowo, \& Saraswati (2013) memperoleh hasil bahwa layanan informasi karir yang diberikan kepada siswa dapat memberikan pengaruh yang positif dan signifikan dalam peningkatan pemahaman siswa tentang cara membuat keputusan karir.

Permasalahan kurangnya jam mengajar guru BK dan terbatasnya waktu memang seringkali menjadi alasan tidak terlaksananya suatu layanan BK di sekolah, tidak terkecuali yang menyangkut dengan layanan bimbingan karir. Akan tetapi seharusnya hal ini tidak dijadikan sebagai penghambat dalam melakukan layanan bimbingan atau layanan informasi karir kepada siswa, apalagi dewasa ini perkembangan teknologi sudah semakin pesat, segala hal dapat dipermudah. 
Saat ini proses konseling juga tidak harus dilaksanakan secara langsung (face to face). Hadirnya layanan cybercounseling atau bimbingan dan konseling berbasis internet menjadi salah satu bukti bahwa konseling seharusnya tidak terbatas pada ruang dan waktu.Hal ini pula yang membuat peneliti tertarik untuk mengembangkan sebuah produk layanan yang berbasis website. Jika layanan bimbingan dan konseling berbasiswebsite sudah banyak dikembangkan, maka peneliti mencoba mengembangkan produk layanan yang lebih spesifik atau lebih khusus di bidang karir karena mengingat bahwa permasalahan yang berkaitan dengan karir menjadi hal yang seringkali dialami oleh siswa khususnya ditingkat SMA yang nantinya akan melanjutkan pendidikannya ke perguruan tinggi atau yang akan memilih untuk bekerja serta berwirausaha.

Layanan ini merupakan layanan informasi karir berbasis media elektronik dengan menggunakan website, dimana website ini akan dijadikan sebagai mediabagi para siswa yang ingin mendapatkan informasi yang menyangkut tentang pilihan program studi atau jurusan yang ada di berbagai universitas, juga informasi seputar pekerjaan dan pilihan karir yang cocok dan sesuai dengan minat, kemampuan maupun karakteristik kepribadian mereka. Media ini juga dapat dijadikan sebagai layanan konsultasi bagi siswa yang bingung dan masih ragu serta belum mampu untuk menentukan atau memutuskan arah pilihan karirnya ke depan.

Keinginan peneliti untuk mengembangkan layanan ini juga disambut baik oleh guru BK yang ada di SMA negeri 3 Makassar. Dari hasil wawancara peneliti dengan guru BK di SMA Negeri 3 Makassar, mereka sangat setuju jika layanan informasi karir berbasis media elektronik website tersebut dapat dikembangkan karena keberadaan layanan tersebut pasti akan sangat membantu guru BK dalam menjalankan tugasnya untuk memberikan pelayanan bimbingan karir kepada siswa tanpa adanya batasan ruang dan waktu, dan hal ini sudah pasti akan sangat membantu siswa dalam memutuskan dan menentukan arah pilihan karirnya.

Kurangnya informasi mengenai pilihan jurusan yang ada di perguruan tinggi atau informasi mengenai pekerjaan yang cocok dan sesuai dengan bakat dan kemampuan siswa jika mereka memilih ingin bekerja setelah tamat SMA nanti, serta siswa yang merasa bingung untuk mengambil keputusan yang tepat menyangkut arah pilihan karirnya,merupakan permasalahan yang banyak dialami oleh siswa tidak terkecuali di SMA Negeri 3 Makassar, sehingga sangat perlu untuk dikembangkan suatu layanan informasi karir terkini yang lebih praktis dan menarik, yang tidak hanya mencakup info tentang jurusan yang ada di perguruan tinggi tetapi juga segala informasi yang berkaitan dengan pekerjaan, dunia kewirausahaan termasuk info tentang bagaimana memilih pekerjaan dan usaha yang cocok dengan bakat dan minat siswa.

Pelayanan informasi pada hakekatnya adalah suatu proses membantu seseorang dengan sarana yang tersedia untuk mendapatkan informasi yang orang butuhkan agar orang dapat memanfaatkannya dengan baik dan mengetahui perkembangan lingkungan sekitarnya bahkan seluruh dunia. Hal ini dapat menjadikan individu memiliki wawasan luas agar dapat membantu dirinya dalam memutuskan keputusan yang tepat baginya.

Aqib (2012) mengungkapkan bahwa layanan informasi merupakan suatu layanan BK yang memungkinkan peserta didik menerima dan memahami berbagai informasi yang dapat digunakan sebagai bahan pertimbangan dalam pengambilan keputusan untuk kepentingannya.

Permasalahan karir merupakan permasalahan masa depan siswa. Kegiatan masa sekarang akan mewarnai masa depan seseorang. Agar siswa SMA dapat menyiapkan masa depannya dengan baik, siswa harus dibekali dengan sejumlah informasi karir yang akan dipilihnya. Informasi yang cukup dan tepat tentang seseorang individu, merupakan aset bagi individu yang bersangkutan untuk memahami faktor-faktor yang ada pada dirinya, faktor kekuatan maupun faktor kelemahankelemahannya. Sukardi (1987: 236) menyatakan "Layanan informasi dalam pelaksanaan bimbingan karir memegang peranan penting, karena informasi adalah merupakan suatu proses yang dinamis dalam menuju suatu sasaran penelitian".

Menurut Hayes \& Hopson (Eko, 2013) informasi karir adalah informasi yang mendukung perkembangan bidang pekerjaan, dan berdasarkan informasi itu memungkinkan seseorang mengadakan pengujian akan kesesuaian dengan konsep dirinya. Lebih lanjut dikatakan informasi karir tidak hanya sekedar merupakan objek faktual, tetapi sebagai 
kemampuan proses psikologis untuk mentransformasikan informasi itu dikaitkan dengan pilihan dan tujuan hidup masa depan.

Beradasarkan uraian di atas dapat disimpulkan bahwa layanan informasi karir merupakan suatu layanan yang diberikan kepada individu atau siswa untuk membantu memperoleh informasi yang dibutuhkan berkaitan dengan pendidikan, pekerjaan atau arah pilihan karirnya, sehingga siswa mampu mengambil keputusan yang tepat untuk kepentingan masa depannya.

Media elektronik adalah media yang menggunakan elektronik atau energi elektromekanis bagi pengguna akhir untuk mengakses kontennya. Sumber media elektronik yang familiar bagi pengguna umum antara lain adalah rekaman video, rekaman audio, dan presentasi multimedia. Media elektronik dapat berbentuk analog maupun digital, walaupun media baru pada umumnya berbentuk digital (Bagus, 2012).

Media elektronik dapat diartikan sebagai perangkat teknologi yang dapat menggantikan media kertas yang biasa digunakan.Media elektronik merupakan sumber informasi yang utama bagi hampir sebagian besar orang saat ini, karena dengan adanya media elektronik tersebut orang dapat mengetahui informasi yang terjadi di sekelilingnya dan bahkan dapat mengetahui informasi yang terjadi di seluruh dunia. Dartias (2010) mengungkapkan media elektronik memiliki beberapa karakteristik, yaitu cepat dalam menyampaikan informasi, dapat menjangkau khalayak yang lebih luas, dan lebih menarik karena dikemas dengan memadukan audio dan visual. Melalui media elektronik ini akses akan informasi bisa di dapatkan masyarakat lebih cepat.

Berdasarkan definisi media elektronik tersebut mengarahkan kita untuk menarik suatu simpulan bahwa media elektronik adalah sebuah perangkat teknologi yang dapat dijadikan perantara dalam menyalurkan informasi dari sumber informasi kepada orang yang membutuhkan informasi.

Tujuan penggunaan media elektronik dalam layanan bimbingan karir adalah agar pemberian informasi dapat dilakukan dengan cara yang lebih menarik, interaktif, dan tidak terbatas tempat, tetapi juga tetap memperhatikan azas-azas dan kode etik dalam bimbingan dan konseling.

Pengambilan keputusan berarti proses penentuan pilihan. Memfasilitasi pengembangan pengetahuan tentang membuat keputusan berarti proses bantuan untuk memudahkan siswa menentukan pilihan, yang dalam konteks ini adalah pilihan karir. Hal ini sangat penting bagi siswa agar keputusan-keputusan hidup selama menjadi siswa dapat mendasari keputusan karir masa depannya.

Freud \& Keith (2010) mengemukakan bahwa decision making is almost universally defined as choosing between alternatives. Artinya, bahwa secara umum pengertian dari pengambilan keputusan adalah memilih diantara berbagai alternatif.

Selanjutnya Way \& Cecil (2010) mengemukakan bahwa pengambilan keputusan merupakan pengambilan siklus kegiatan yang melibatkan pemikiran rasional baik secara individu maupun kelompok dalam semua tingkat dan bentuk organisasi. Esensi dari sebuah pengambilan keputusan adalah proses penentuan pilihan. Secara alami, manusia akan diperhadapkan kepada berbagai pilihan dan secara alami juga dilatih mengambil keputusan dari pilihan-pilihan hidup yang dialaminya. Oleh karena itu sesungguhnya manusia akan terusmenerus menentukan pilihan hidup dari waktu ke waktu sampai akhir kehidupannya. Proses inilah yang disebut dengan pengambilan keputusan. Hanya saja pada kenyataannya ada individu yang mampu dengan tepat mengambil keputusan ada juga yang tidak mampu.

Terry (Mahtika, 2007: 53) mendefinisikan "Decision making can be definedas he selection of one behavior alternative from two our more posible alternatives". Artinya pengambilan keputusan adalah pemilihan alternatif perilaku dari alternatif atau dari beberapa alternatif yang ada.

Selanjutnya menurut Crites (Munandir, 1996) istilah karir menunjukkan sifat development dari pengambilan keputusan karir, yaitu bahwa pengambilan keputusan itu suatu proses dan proses itu berlangsung sepanjang hayat. Jadi yang dimaksud pengambilan keputusan karir adalah sesuatu yang telah ditetapkan oleh individu mengenai pekerjaan dan kedudukan yang mengarah pada kehidupan dalam dunia kerja yang akan ditekuni sepanjang hidupnya. Siagian (Hasan,

2002) 
mengungkapkan pengambilan keputusan adalah suatu pendekatan yang sistematis terhadap hakikat alternatif yang dihadapi dan mengambil tindakan yang menurut perhitungan merupakan tindakan yang paling tepat. Pendapat ini menyebutkan bahwa pemikiran yang rasional merupakan landasan dalam pengambilan sebuah keputusan, karena pilihan terhadap alternatif memiliki plus-minus atau manfaat dan konsekuensi yang menyertai setiap pilihan, dan rasionalitas sangat berperan penting dalam pengambilan keputusan terhadap konsekuensi yang ada.

Pengambilan keputusan karir menurut Tolbert (Manrihu, 1992: 33) merupakan"Suatu proses sistematis dari berbagai data yang digunakan dan dianalisis atas dasar prosedurprosedur yang eksplisit dan hasil-hasilnya dievaluasi sesuai dengan yang diinginkan". Pendapat di atas menyebutkan bahwa dalam suatu pengambilan keputusan ada berbagai proses yang dilalui serta sebelum mengambil suatu keputusan ada berbagai data atau informasi yang perlu dianalisis.

Berdasarkan pendapat beberapa ahli tersebut maka dapat disimpulkan bahwa pengambilan keputusan karir merupakan suatu proses sistematis terhadap pilihan pekerjaan atau karir yang ditetapkan individu, yang diperoleh dari pengumpulan informasi dan persiapan untuk memasuki dunia kerja, yang akan ditekuni sepanjang hidupnya.

\section{METODE}

Model Pengembangan penelitian ini dilakukan dengan menggunakan pendekatan "Penelitian Pengembangan" (Research and Development). Menurut Borg \& Gall (2003: 782), penelitian dan pengembangan adalah " $A$ process used develop and validate educational product". Setyosari (2013: 222) mengungkapkan "Penelitian dan pengembangan ini kadang kala disebut juga sebagai suatu pengembangan berbasis pada penelitian atau disebut juga research based development". Dalam penelitian ini, Research and Development dimanfaatkan untuk menghasilkan layanan informasi berbasis media elektronik (e-career) melalui website untuk meningkatkan keputusan karir siswa di SMA Negeri 3 Makasaar.

Prosedur Pengembangan. Prosedur yang dilalui dalam penelitian dan pengembangan produk layanan e-career ini adalah sebagai berikut:

\section{Pra pengembangan produk:}

1. Analisis kebutuhan

2. Penelitian Awal dan Pengumpulan informasi

3. Perencanaan pengembangan

\section{Pengembangan produk:}

1. Pengembangan produk awal

2. Uji ahli (validasi ahli)

3. Revisi I

\section{Pasca pengembangan produk:}

1. Uji coba kelompok kecil

2. Revisi II

3. Uji kelompok besar

4. Revisi akhir 
Tempat dan Waktu Pengembangan. Penelitian pengembangan ini dilakukan di SMA Negeri 3 Makassar setelah terlebih dahulu mengadakan observasi dan wawancara untuk memperoleh data informasi. Sekolah tersebut dipilih karena adanya kebutuhan siswa akan suatu layanan informasi karir yang efektif dan efisien. Kegiatan layanan bimbingan karir dan layanan informasi karir yang diberikan oleh guru BK kepada siswa sangat jarang dilaksanakan karena adanya keterbatasan waktu.

\section{Uji Coba Produk}

1. Tahapan Uji Ahli

Pada tahap uji coba awal peneliti mengujikan produk layanan e-career ini kepada 3 orang ahli, yang pertama ahli materi BK, yang kedua ahli media teknologi pendidikan dan yang ketiga merupakan praktisi BK di lapangan atau sekolah. Proses uji ahli ini bertujuan untuk memberikan validasi produk layanan e-career melalui website sebelum dilakukan uji coba pada kelompok kecil dan kelompok besar.

2. Uji coba produk

Selanjutnya Uji coba kelompok kecil terdiri dari 6 orang Guru BK SMA Negeri 3 Makassar, dan uji coba kelompok besar terdiri dari 30 orang siswa kelas XII di SMA Negeri 3 Makassar.

Subjek uji coba. Subjek uji coba terdiri dari ahli materi BK, ahli media teknologi pendidikan, guru BK serta siswa. Adapun siswa yang menjadi subjek uji coba dalam penelitian ini adalah siswa kelas XII di SMA Negeri 3 Makassar yang diambil dengan menggunakan teknik purposive sampling atau sampel bertujuan. Menurut Arikunto (2002) purposive sampling dilakukan dengan cara mengambil subyek bukan didasarkan atas strata, random, atau daerah, tetapi didasarkan atas adanya tujuan tertentu.

Jenis Data. Data-data yang diperoleh dalam pengembangan layanan e-career melalui website ini berupa data kualitatif dan kuantitatif. Data kualitatif diperoleh dari hasil tanggapan, kritik dan saran dari para ahli dan kelompok terhadap isi dan tampilan website. Kemudian kritik dan saran tersebut dianalisis sebelum dijadikan sebagai bahan revisi produk yang dikembangkan.

Data kuantitatif diperoleh dari hasil uji coba kelompok yang berupa penilaian secara umum mengenai website yang di dalamnya terdapat layanan e-career. Data kuantitatif yang didapatkan kemudian diolah untuk menunjukkan taraf kelayakan. Selanjutnya seluruh data, baik data kualitatif maupun kuantitatif yang diperoleh digunakan sebagai dasar untuk merevisi produk layanan e-careerini.

Instrumen Pengumpulan Data. Penelitian ini menggunakan tiga macam instrumen pengambilan data, meliputi wawancara (interview), skaladan angket, dan focus group discussion (FGD).

Instrument dalam penelitian

pengembangan ini khususnya berupa angket dilakukan dengan cara validitas logis. Menurut Arikunto (2002: 167) sebuah instrumen dikatakan memiliki validitas logis apabila instrumen tersebut secara analisis akal sudah sesuai dengan isi dan aspek yang diungkap, dan untuk memperoleh instrumen yang memiliki validitas logis baik dari isi maupun aspeknya, peneliti melakukan perencanaan penyusunan instrumen dengan membuat kisi-kisi instrumen. Selanjutnya, peneliti meminta pendapat ahli dalam mencermati kesesuaian instrumen yang telah disusun dengan hal-hal yang ingin diungkap.

Teknik analisis data yang digunakan untuk mengolah data yang diperoleh dalam pengembangan model layanan informasi karir ini adalah dengan menggunakan analisis isi dan analisis deskriptif.

Analisis data kualitatif dilakukan dengan menggunakan analisis isi, yaitu mengelompokkan informasi-informasi data kualitatif berupa tanggapan, masukan, serta kritik dan saran yang diperoleh dari para ahli, untuk merevisi media tahap awal. Selanjutnya tanggapan, kritik serta saran dari guru BK sebagai subyek uji coba kelompok kecil dijadikan bahan untuk merevisi media pada tahap ke dua, sedangkan komentar siswa digunakan untuk merevisi media pada tahap revisi akhir.

Analisis data kuantitatif dilakukan dengan analisis deskriptif kuantitatif, yaitu untuk menganalisis data kuantitatif yang diperoleh dari angket atau skala lembar evaluasi yang diperoleh dari uji coba kelompok.

\section{HASIL DAN PEMBAHASAN}

Komponen pra pengembangan model. Berdasarkan hasil pengamatan dan observasi langsung di SMA Negeri 3 Makassar, diperoleh 
informasi bahwa belum ada program-program yang bertujuan untuk membantu meningkatkan keputusan karir siswa.Program-program yang dimaksud dapat berupa kegiatan bimbingan karir maupun layanan informasi karir yang praktis, efektif dan efisien dalam membantu siswa meningkatkan keputusan karirnya.

Dari hasil survei melalui wawancara kepada guru BK dan observasi langsung di SMA Negeri 3 Makassar diketahui bahwa kegiatan bimbingan karir atau layanan informasi karir biasanya diberikan kepada siswa dalam bentuk sosialisasi perguruan tinggi yang dilakukan oleh beberapa universitas, sehingga informasi yang diperoleh oleh siswa seringkali tidak begitu jelas dan lengkap. Selain itu banyak pula siswa yang sering datang menemui guru Bimbingan dan Konseling untuk mengkonsultasikan atau menanyakan berbagai hal yang berkaitan dengan masa depan karirnya, baik itu yang menyangkut jurusan atau program studi apa yang sebaiknya mereka pilih di perguruan tinggi nanti, maupun jenis pekerjaan yang tepat dan sesuai dengan bakat dan kemampuan mereka. Hal ini membuktikan bahwa banyak siswa yang masih bingung untuk memilih karir yang tepat dan sesuai dengan bakat dan kemampuan yang dimilikinya, sehingga mereka membutuhkan suatu layanan informasi yang dapat membantu mereka dalam memilih karirnya ke depan, akan tetapi keterbatasan waktu menjadi kendala sehingga pelaksanaan pemberian layanan informasi karir belum terlaksana secara optimal.

Hasil analisis kebutuhan yang dilakukan oleh peneliti tidak hanya didasarkan pada asumsi-asumsi dalam menganalisis kebutuhan saja tetapi juga pada hasil studi pendahuluan yang dilakukan di sekolah dengan menggunakan teknik survey melalui angket atau kuesioner yang diberikan pada 30 siswa di SMAN 3 Makassar.

Dari hasil angket atau kuesioner yang diberikan pada 30 orang siswa kelas XII di SMA Negeri 3 Makassar, diperoleh hasil yakni sekitar $70 \%$ siswa belum dapat mengambil keputusan karir dan masih bingung untuk menentukan pilihan jurusan atau program studi yang tepat, serta memilih bidang pekerjaan yang nantinya akan ditekuni, sehingga mereka sangat membutuhkan adanya suatu layanan informasi dengan model layanan informasi karir berbasis media elektronik(e-career) untuk membantu dalam memilih jurusan atau program studi maupun pekerjaan yang sesuai dengan bakat, minat serta kemampuan yang mereka miliki, agar nantinya dapat memilih dan memutuskan arah pilihan karirnya kedepan dengan lebih baik.

Hal inilah yang akhirnya membuat peneliti melakukan penelitian pengembangan layanan informasi karir berbasis media elektronik(e-career) untuk membantu meningkatkan keputusan karir siswa di SMA Negeri 3 Makassar.

Komponen pengembangan model.

1. Pengembangan model awal

Model layanan informasi karir berbasis media elektronik (e-career) yang digunakan dan dikembangkan dalam penelitian ini adalah suatu layanan informasi karir dalam bentuk website yang berisi berbagai informasi pengenalan bakat dan minat siswa, informasi berbagai jurusan yang ada di perguruan tinggi, serta informasi jenis-jenis pekerjaan dan wirausaha. Selain itu terdapat juga beberapa tes-tes pengenalan diri, bakat dan minat karir yang tersedia untuk dapat membantu siswa mengetahui arah pilihan karirnya ke depan. Pengembangan model layanan informasi karir berbasis media elektronik yang dilakukan oleh peneliti merupakan hasil dari kebutuhan-kebutuhan siswa di sekolah dan guru bimbingan dan konseling selaku pembimbing dan pendidik.

\section{Hasil uji validasi ahli}

Berdasarkan hasil penilaian angket akseptibilitas mengenai kegunaan, kelayakan dan ketepatan model layanan informasi karir berbasis media elektronik (e-career) untuk meningkatkan keputusan karir siswa yang telah diberikan oleh tiga ahli yaitu Dr.Abdul Saman, M.Si., Kons., selaku ahli materi bimbingan dan konseling, Dr.NurhikmahH.S.Pd., M.Si., selaku ahli media teknologi pendidikan, dan Ramdana, S.Pd., M.Pd., selaku praktisi di lapangan atau sekolah, maka dapat disimpulkanbahwa model layanan informasi karir (e-career)telah layak untuk dilakukan atau diberikan pada siswa di SMA Negeri 3 Makassar.

\section{Revisi I}

Berdasarkan data yang masuk dari para ahli dan dianalisis dan hasil analisisnya, pada dasarnya ketiga ahli mengatakan bahwa model layanan informasi karir berbasis media elektronik (ecareer) untuk meningkatkan keputusan karirsiswa yang telah ada sudah baik untuk digunakan dan diberikan kepada siswa. Meskipun demikian ada beberapa saran yang 
diberikan oleh para ahli. Hasil revisi tahap pertama untuk uji coba ahli (validasi) model layanan informasi karir berbasis media elektronik (e-career) untuk membantu meningkatkan keputusan karirsiswa ini selanjutnya diujikan pada uji coba tahap berikutnya, yaitu uji coba pada kelompok kecil.

Komponen Pascapengembangan model.

1. Uji kelompok kecil

Berdasarkan hasil uji kelompok kecil yang diberikan kepada 6 orang guru bimbingan dan konseling di SMA Negeri 3 Makassar, dapat disimpulkan bahwa secara keseluruhan layanan e-career sangat baik dan menarik. Berbagai layanan yang ada pada website atau layanan $e$ career tersebut sangatlah bermanfaat bagi siswa dalam mengenal bakat dan minatnya serta dapat membantu siswa dalam menentukan arah pilihan karirnya ke depan, sehingga model layanan informasi karir berbasis media elektronik atau layanan e-career ini sangat perlu untuk segera diterapkan di sekolah khususnya di SMA Negeri 3 Makassar.

2. Revisi II

Revisi kedua ini dilakukan berdasarkan data hasil uji kelompokkecil yang telah dilaksanakan. Berbagai respon, komentar dan saran dari guru bimbingan dan konseling dijadikan sebagai bahan analisa dalam melakukan revisi ke dua pada model layanan informasi karir berbasis media elektronik (e-career) ini.

3. Uji kelompok besar

Uji coba kelompok besar bertujuan untuk mengetahui pengaruh model layanan informasi karir berbasis media elektronik (e-career) yang telah dikembangkan dan hal apa saja yang perlu direvisi sebelum menentukan produk akhir. Uji kelompok besar melibatkan 30 siswa kelas XII.Tingkat keputusan karir siswa di SMA Negeri 3 Makassar sebelum diberikan model layanan informasi karir berbasis media elektronik (e-career) dalam kategori rendah sebanyak 26 responden $(86,66 \%)$, kemudian kategori tinggi sebanyak 4 responden $(13,33 \%)$, untuk kategori sangat rendah tinggi dan sangat tinggi tidak terdapat sama sekali responden pada kategori tersebut. Namun setelah diberikan model layanan informasi karir berbasis media elektronik (ecareer), maka tingkat keputusan karir pada siswa menunjukkan peningkatan, dimana pada kategori sangat tinggi sebanyak 9 responden $(30 \%)$ dan tingkat kategori tinggi sebanyak 21 responden
(70\%), sementara untuk kategori sangat rendah dan rendah tidak terdapat responden.

Berdasarkan hasil penghitungan dengan menggunakan SPSS 20 melalui paired sample ttest terdapat perbedaan nilai rata-rata setelah perlakuan lebih tinggi dari sebelum diberikan perlakuan model layanan informasi karir berbasis media elektronik (e-career), dengan nilai $\mathrm{t}=$ 15,011 dengan $\mathrm{df}=29$ Harga $\mathrm{t}_{\text {tabel }}$ pada $\mathrm{t}{ }_{0,05}$ $=2,045$ dengan nilai signifikan $(\mathrm{P})=0,000<\alpha=$ 0,05 . Hal ini berarti bahwa hipotesis nihil $\left(\mathrm{H}_{0}\right)$ yang berbunyi "Tidak ada pengaruh positif terhadap keputusan karir siswa setelah penerapan model layanan informasi karir berbasis media elektronik (e-career) diterapkan di SMA Negeri 3 Makassar" dinyatakan ditolak. Sehingga hipotesis kerja $\left(\mathrm{H}_{1}\right)$ yaitu "model layanan informasi karir berbasis media elektronik efektif dalam meningkatkan keputusan karir siswa SMA Negeri 3 Makassar" dinyatakan diterima. Berdasarkan hasil pengujian kelompok besar dengan melibatkan sebanyak 30 siswa menggunakan mean dari gain skor yaitu rata-rata dari selisih skor sebelum dan sesudah pemberian model layanan informasi karir berbasis media elektronik yaitu sebesar 75,5000 sebelum pemberian layanan e-career dan 98,2667 sesudah pemberian model layanan e-career. Berdasarkan uji perbedaan hasil sebelumdan sesudah pemberian model layanan informasi karir berbasis media elektronik (e-career) pada uji kelompok besar 30 subjek mengalami peningkatan sebesar 15,011. Hal ini berarti bahwa model layanan e-career dapat meningkatkan keputusan karir siswa SMA Negeri 3 makassar.

Adapun untuk mengukur tingkat keberterimaan dan respon siswa terhadap layanan $e$-career, peneliti memberikan angket yang berisi pertanyaan tertutup beserta kolom komentar kepada 30 orang siswa yang telah mendapatkan pemberian layanan e-career melalui media website. Hasil yang diperoleh melalui pemberian angket respon siswa tersebut yakni $90 \%$ siswa memberikan respon positif atas adanya layanan e-career yang menurut mereka sangat bermanfaat dan dapat membantu dalam mengenal diri, bakat dan kemampuan, juga dapat mengetahui informasi tentang berbagai jurusan dan perguruan tinggi, serta informasi pekerjaan dan wirausaha. Selain itu siswa juga memberikan komentar dan saran yang berkaitan dengan layanan informasi jurusan yang terdapat dalam 
layanan e-career agar lebih ditambahkan lagi daftar bidang atau program studi sehingga lebih bervariasi.

\section{Revisi akhir}

Berdasarkan data kuantitatif dan kualitatif yang diperoleh dari validasi ahli, uji kegunaan, kelayakan dan uji ketepatan maka model layanan informasi karir berbasis media elektronik untuk meningkatan keputusan karir telah layak diterima dan dapat digunakan sebagai pedoman dalam pemberian layanan bimbingan karir maupun layanan informasi karir kepada siswa di sekolah. Berdasarkan data yang diperoleh menunjukkan bahwa model layanan informasi karir berbasis media elektronik (e-career) untuk meningkatkan keputusan karirsiswa tidak perlu direvisi. Adapun revisi tahap akhir ini lebih didasarkan pada data kualitatif, berupa saran dan komentar.

5. Model akhir layanan $e$-career

Pada tahap ini layanan informasi karir berbasis media elektronik (e-career)telah mencapai tahap akhir dimana layanan e-career sudah mampu digunakan sebagai layanan informasi karir bagi siswa juga bagi guru BK dalam membantu siswa meningkatkan keputusan karirnya. Setelah melaksanakan tahapan-tahapan penelitian diatas, maka lahirlah model akhir layanan e-career yang telah diujikan oleh ahli tingkat validitasnya, atau kebergunaannya serta keberterimaannya dilapangan.

Adapun isi materi dan tampilan dari layanan informasi karir berbasis media elektronik (ecareer) ini adalah sebagai berikut:

Beranda/Homepage: halaman muka atau halaman utama website atau layanan e-career yang memuat informasi singkat tentang apa isi website tersebut. Pada beranda layanan e-career nanti akan memuat diantaranya info dan berita seputar karir, penelusuran minat karir, layanan diskusi dan konsultasi karir, gambar, poling web, dan lain-lain;

Profil: di dalam profil website akan memuat pengantar website atau layanan e-career, pengertian dan tujuan layanan bimbingan dan konseling karir, konselor sebaya, serta kontak profil admin layanan $e$-career;

Program: program terdiri dari program-program layanan BK seperti, kegiatan konseling karir, career day,

Layanan informasi karir: berisi informasi tentang mengenal minat karir siswa; informasi dengan topik memahami dan mengenal karakteristik dan kepribadian siswa; layanan informasi dengan topik mengenal kekuatan dan kelemahan diri; informasi tentang macammacam fakultas dan jurusan di perguruan tinggi; layanan informasi karir dengan topik memilih jurusan di perguruan tinggi; layanan informasi karir dengan topik memasuki dunia kerja; layanan informasi karir dengan topik memilih pekerjaan yang tepat sesuai dengan minat dan bakat siswa.

\section{SIMPULAN DAN SARAN}

Pengembangan model layanan informasi karir berbasis media elektronik (e-career) yang acceptable (diterima) berdasarkan kegunaan (utility), ketepatan (accuracy) dan kelayakannya (feasibility)untuk meningkatkan keputusan karir siswa mendapat skala penilaian tinggi dari para ahli dan respon yang sangat baik dari guru bimbingan konseling juga siswa yaitu dapat diterima dan layak untuk digunakan di SMA Negeri 3 Makassar.

Penerapan model layanan informasi karir berbasis media elektronik (e-career) efektif dalam meningkatkan keputusan karir siswa SMA Negeri 3 Makassar.

Berdasarkan hasil penelitian ini, diharapkan kepada beberapa pihak untuk menindaklanjuti sebagai berikut: 1) Hasil penelitian ini menunjukkan bahwa model layanan informasi berbasis media elektronik (ecareer), baik dari segi konseptual maupun dari segi praktis memiliki kelayakanuntuk diimplementasikan disekolah. Dari segi pengembangan ilmu, model bimbingan atau layanan informasi karir dapat memberikan kontribusi bagi pengembangan ilmu bimbingan dan konseling khususnya dalam bidang bimbingan karir., 2) Model layanan informasi karir berbasis media elektronik (e-career) ini didasarkan pada kebutuhan akanadanya suatu model yang dapat digunakan oleh guru bimbingan konseling dalam membantu siswa meningkatkan keputusan karirnya. Terutama bagi mereka yang kurang memiliki pengetahuan tentang berbagai jurusan yang ada diperguruan tinggi serta informasi bidang pekerjaan yang sesuai dengan bakat, minat dan kemampuannya. Berdasarkan pertimbangan kebutuhan dan masalah tentang bimbingan dan layanan informasi karir tersebut maka hasil penelitian ini direkomendasikan untuk dilaksanakan di sekolah 
agar dapat membantu konselor dalam membantu siswa meningkatkan keputusan karirnya., 3) Model ini baru dikembangkan dan diuji cobakan pada sebagian kecil siswa di satu sekolah saja, oleh karena itu para peneliti selanjutnya direkomendasikan untukdapat menelaah atau mengembangkan dan mengujicobakan model ini pada sasaran-sasaran yang lebih beragam dan luas.

\section{DAFTAR RUJUKAN}

Aqib, Z. 2012. Ikhtisar Bimbingan \& Konseling di Sekolah. Bandung: YRAMA WIDYA.

Arikunto, S. 2002. Prosedur Penelitian suatu pendekatan praktek. Jakarta: Rineka Cipta.

Bagus, R. 2012. Media Elektronik dan Media Massa, (online), (http://rayesbatamtoday2012.blogspot.co m/2012/01/media-elektronik-dan-mediamassa.html, diakses 10 juni 2014).

Borg, W.R. \& Gall, M.D. 2003.Educational Research : an Introduction. New York: Longman.

Dartias, D. 2010. Media Massa ; Definisi, Karakteristik dan Fungsi, (online), (http://devitadartias.blogspot.commediamassa.html, Diakses 7 Mei 2014).

Eko. 2013. Bimbingan dan Konseling Karir, (online),(http://ekodageink.blogspot.com Diakses 17 April 2014).

Freud \& Keith. 2010. Peta Masa Depanku, (Online),

(http://petamasadepanku.comDiakses pada tanggal 5 maret 2014).

Hasan, M. I. 2002. Pokok-Pokok Materi Metodologi Penelitian dan Aplikasinya. Indonesia: Ghalia.

Kurnianto, P. 2010. Efektifitas Layanan Informasi Bimbingan Karir Terhadap Ketepatan Pemilihan Karir Siswa. Perpustakaan Online Universitas Pancaksakti Tegal.

Leksana, D.M., Wibowo, M.E., Tadjri, I. 2013.Pengembangan Modul Bimbingan Karir Berbasis Multimedia Interaktif Untuk Meningkatkan Kematangan Karir Siswa.Jurnal Online Universitas Negeri Surabaya, (online), (http://ejournal.unesa.ac.id, Diakses 3 Maret 2014).
Mahtika, H. 2007. Pengambilan Keputusan Stratejik. Makassar: Badan Penerbit UNM.

Manrihu, M. T. 1992. Pengantar Bimbingan dan Konseling Karir. Ujung Pandang: FIP IKIP.

Munandir. 1996. Program Bimbingan Karir di sekolah. Jakarta: Depdikbud.

Muslihatul, Y. \& Nursalim, M. 2013. Meningkatkan Pemahaman Karier Siswa dengan Pemberian Layanan Informasi Karier di Kelas XI IS-4 SMA Negeri 13 Surabaya(Suatu Penelitian Tindakan Dalam Bimbingan dan Konseling). Jurnal Online Universitas NegeriSurabaya, (online), (http://ejournal.unesa.ac.id, Diakses 5 Maret 2014).

Setyosari, P. 2013. Metode Penelitian Pendidikan \& Pendidikan. (cetekan ketiga). Jakarta: Prenadamedia Group.

Sukardi, K. 1987. Bimbingan Karir di SekolahSekolah. Jakarta: Ghalia Indonesia.

Way K. \& Cecil, G. 2010.Peta Masa Depanku, (Online), (http://petamasadepanku.com, diakses pada tanggal 5 maret 2014). 